\title{
The Motivation for Corporate Institutions to Invest Funds in Public Schools
}

\author{
Raj Mestry \\ University of Johannesburg \\ Jacques Verster
}

University of Johannesburg

\section{Doi:10.5901/mjss.2014.v5n23p176}

\begin{abstract}
More recently, the state has tactfully appealed to corporate institutions to channel available funds to public schools. The Broad Based Black Economic Empowerment Act of 2003 stipulates that corporate institutions should spend at least one percent of its profit after tax on socio-economic development. Corporate institutions have the option of directing funds to educational institutions or steering funds to institutions outside of education. This paper examines the rationale behind corporate institutions providing funding to public schools: Some of the corporate institutions may want to realise economic growth over the long-term; some hope to gain or sustain consumer and employee loyalty in the short/medium-term. A qualitative research method was used to explore the motivation for corporate institutions, located in the central district of Cape Town, channeling funds to public schools. This study was anchored on the assumption that the sustainability of corporate funding in public schools is dependent on the achievement of high returns (or excessive profits). Some findings revealed that corporate institutions use stringent criteria to provide funds to schools; community relations are strengthened when schools are provided with additional funding; and the sustainability of funds in public schools is potentially dependent on the level of employee and community involvement.
\end{abstract}

Keywords: corporate, funding, social responsibility, state, public schools, funding proposal

\section{Introduction and Background to the Problem}

The inability of the state to fund public schools sufficiently has compelled public schools to explore other avenues of funding that will enable them to provide quality education for all learners. Even though section 34 of the South African Schools Act (South Africa, 1996), makes provision for the state to fund public schools on an equitable basis and acknowledges its responsibility of making education more affordable and accessible to all, especially the poor, the state is unable to achieve its mandate with limited financial resources.

According to the National Norms and Standards for School Funding (NNSSF) policy (South Africa, 1998), all public schools should be ranked and funded according to quintiles. The quintile rankings of public schools are based on the poverty or wealth levels of the community; the available resources of schools according to the School Building Audit; and the income levels of parents/guardians of learners using the Community Poverty Indicator Survey. Poor schools (quintile 1 and quintile 2) will receive more funding from the state than affluent schools (quintile 4 and quintile 5). The middle of the range schools are classified as quintile 3 and receive a subsidy referred to as the 'adequacy benchmark'. Schools will receive a minimum amount or more (quintile 1 and 2) or less (quintile 4 and 5) than this 'adequacy benchmark' depending learner enrolment. For the past sixteen years, quintile 1 and 2 schools have been declared "no fee" schools and are legally prohibited from charging user-fees or school fees from parents (Motala \& Dieltiens, 2010:2). More recently, to alleviate the financial burden of poor parents, the concept of 'no fee' schools has been extended to the middle of the range (quintile 3) schools.

Despite substantial funding from the state, learner performance and the provision of quality education in poorer schools has not improved significantly. However, affluent schools continue to perform favourably despite receiving less funding from the state (Motala \& Dieltiens, 2010:2). It appears that equitable and democratic participation in quality teaching and learning practices in public schools are dependent on substantial funding, and the wealth and influence of a school's community (Karlson, McPherson \& Pampallis, 2001:144-145), rather than on increased state contributions (Veriava, 2010:12). Hence, schools serving wealthy and influential communities have greater access to physical and financial resources, and attract better qualified teachers than poorer schools (Karlsson, et al., 2001:144-145). 
The quintile 4 and 5 schools are legally allowed to charge school fees (South Africa, 1996) and they have the means to further enhance the quality of teaching and learning practices offered (Spaull, 2012:12) through various fundraising initiatives (Hanushek \& Wößmann, 2007:20; Veriava, 2010:12). These schools can afford teacher salary topups to attract the best available teachers, employ additional teachers above the post-provisioning norm determined by the Department of Education to reduce the teacher-learner ratios, and upgrade school infrastructure to enhance the delivery of quality teaching and learning practices (Veriava, 2010:12). These opportunities are often denied to the many poor schools (Seekings \& Natrass, 2006:396). Many of the SGBs of poorer schools lack the necessary financial knowledge and skills to come up with innovative or creative ideas to attract additional funding. Some SGBs are not competent or not always committed to find ways of supplementing state funds to enhance quality in education practices (Blake, 2008:9395; Makhubela, 2005:58; Statz \& Weber, 2010:8-11). The competence of SGBs in poor schools is further hindered by a lack of expertise regarding legal matters, financial decisions, business dealings and educational bureaucracy (Pampallis, 2005:23). The commitment of SGBs is restricted by school staff intimidating parent governors, and also that they do not receive any remuneration for their services and time taken from their full-time employment. Self-employed members of SGBs are not allowed to render services for a fee due to potential conflicts of interest (Tladi \& Mulaudzi, 2003:129-130).

Although most SGBs are aware of the importance of raising additional funds to enhance education quality, they don't put measures in place to implement successful fundraising initiatives (Author 1, 2004:129; Blake, 2008:93-95). Research has shown that fundraising projects such as donations, fun-days, raffles, and sport tournaments are proving to be unsuccessful, especially where parents and the broader community are forced to contribute from their personal funds (Flanagan, 2011:1). Also, many SGB initiatives to supplement state resources have been ineffective due to poor planning and ineffective organisation, and/or their lack of creativity and innovation (Griesel, 2011:370). To further complicate this matter, Griesel (2011:370) found that stakeholders quickly become saturated with donation requests from nearby schools. It is understandable that most schools opt to charge school fees instead of solely relying on fundraising activities to supplement state resources (Blake, 2008:93-95; Motala, 2005:51). The South African Schools Act (South Africa, 1996) makes provision for public schools to supplement state resources through levying school fees from parents if they experience budget shortfalls (Blake, 2008:93-95). Even though affluent schools charge exorbitant school fees they are compelled to grant fee exemptions to parents who cannot afford to pay, or suffer the consequence of bad debts. The state invariably claims that free education is provided to all without considering that many affluent schools have to charge school fees to make up for the low funding received from the state (Makhubela, 2005:54). This belief is turned into action as non-contributors are protected by pro-poor funding policies focusing on school fee exemptions, social grants and 'nofee' schools (Motala \& Dieltiens, 2010:1). Although certain parents avoid paying school fees, some simply cannot afford to pay the fees due to the current economic climate and the ever increasing costs of basic essentials (Pampallis, 2005:29). Parents in poorer communities believe that they do not have to contribute financially to a school (Makhubela, 2005:54). Thus, schools are compelled to find other fundraising initiatives to generate funds from external sources (interested individuals, corporate institutions, religious organisations and the broader community) to make up for inadequate state funding and unpaid school fees (Motala, 2005:51).

Based on the above, the research question for this study can be framed as follows: What is the motivation for corporate institutions to invest funds in public schools?

The sub-questions for this study were:

- What do we understand by the concept 'corporate funding'?

- What criteria are used by the corporate institutions to invest funds to schools?

- How can SGBs strengthen their initiatives to solicit and sustain corporate funding for their schools?

In the following sections the aim statement and methodology will be discussed.

\section{Aim Statement}

The general aim of this study was to investigate the motivation for corporate institutions investing funds in public schools. The objectives were to:

- understand what is meant by 'corporate funding' in public schools;

- establish the criteria used by corporate when nominating a school as a beneficiary; and

- explore how SGBs can solicit and sustain corporate funding for their schools. 


\section{Methodology}

To achieve the aim and objectives of the study a qualitative research methodology was used (Caelli, Ray \& Mill, 2003:4). Generic qualitative research was suitable for this particular study since the researchers wanted to understand the motivation for corporate institutions making funds available to public schools (Leedy \& Ormrod, 2005:133). Corporate institutions were required to provide a clear understanding of why they chose to fund public schools without identifying quantitative trends of the phenomenon (De Vos, Strydom, Fouche \& Delport, 2002:79).

Random sampling was used to select five corporate companies from a population $(n=56)$ of socially responsible companies listed in the Corporate Social Investment Handbook (Trialogue, 2008:viii-xv; Flick, 2007:27). The Handbook consists of a list of South African corporate institutions that have funded various organizations including public schools. The company's Chief Executive Officers (CEO) or their delegated representatives (finance officers) of every sampled corporate company agreed to participate in this study. The CEOs/finance officers were approached because we ascertained that they had final decision-making powers regarding the availability and distribution of funds.

Data was collected through an open-ended electronic questionnaire, telephonic follow-up interviews and media document analysis focusing on corporate institutions' social involvement (Leedy \& Ormrod, 2005:135). The electronic questionnaire extracted the institutions' criteria and motivation for funding various organisations including public schools. Media and other relevant documents were analysed to support claims made in the questionnaire, and also to provide additional data that were not feature in the questionnaire. Documents that were analysed included the sampled corporate institutions' websites, policies, publications and newsletters of schools who received funding from these corporate institutions, newspaper articles and other relevant media publication such as the CSI handbook series, Financial Mail, Economist and Business Times. The telephonic interviews and open-ended electronic questionnaires were analysed using Tesch's (1990:142-145) coding method.

To ensure trustworthiness, a pilot study was undertaken with two companies that did not feature in the sample. A structured, open-ended electronic questionnaire was forwarded to each participant using the same format and sequence of words and questions (Cohen, Manion \& Morrison, 2011:204). Furthermore, Guba's (1981) trustworthiness model was used (Krefting, 1990:215-217): To ensure credibility the researcher went back to the sampled institutions' representatives to verify the transcriptions of telephonic interviews, analysis of the open-ended electronic questionnaire and media documents were made. Furthermore, the researchers undertook a literature control to ensure dependability of the study. Consistency of data was also taken into account in the event that the study had to be replicated with the same subjects. Finally, to ensure confirmability, the neutrality of the data was considered.

The researchers also devoted attention to the ethical considerations of this study. Ethical clearance had been obtained from the Ethics Committee of the University of Johannesburg and permission was obtained from the five corporate institutions sampled. Participants were not subjected to 'unusual stress, embarrassment or loss of self-esteem' (Leedy \& Ormrod, 2005:101) and corporate representatives were informed that their participation was voluntary and that they could withdraw from the research at any stage. All participating corporate institutions' names were changed to ensure confidentiality and anonymity (Leedy \& Ormrod, 2005:102).

\section{Understanding the Concept 'Corporate Funding'}

To elucidate the concept 'corporate funding', we need to first understand the concept 'corporate social responsibility' (CSR). CSR is the umbrella term for all socially responsible activities which society expects corporate institutions to participate in to justify the profits they make (Ludescher et al., 2008:322-331). It is a corporate institution's contribution to the community's sustainable development goals (Waddock, 2008:54). The focus is on improving the quality of life of all citizens by focusing on social and environmental problems (Trialogue, 2008:18). Although CSR is seen as a voluntary activity internationally, it is legislated locally by means of the BBBEE Act of 2003 (South Africa, 2003). This Act prescribes that corporate should spend at least 1 percent of its net-profit after tax on CSR (Trialogue, 2008:30).

CSR concentrates on equipping disenfranchised individuals with skills and/or resources to participate actively in the economy (Esser \& Dekker, 2008:157; Trialogue, 2008:19). According to Butler (2009:53), the bulk of disenfranchised individuals are black. The highly unequal distribution of resources during the apartheid regime is perceived to be the main cause of this lasting phenomenon (Bray, Gooskens, Kahn, Moses \& Seekings, 2010: 177). Therefore, corporate institutions are expected to support the transformation of the broader society by improving the livelihood of the previously disadvantaged communities (by redressing past injustices) (Bernstein, 2009:34; Butler, 2009:53; Esser \& Dekker, 2008:157). 
From the above discussion, we observe that CSR is synonymous to corporate funding. There is an increase in the number of corporate institutions that are investing funds in education to fulfil their social responsibility as corporate citizens (Scherer \& Palazzo, 2008:iii). The more popular investments in education by the corporate sector include bursaries, grants (Bernstein, 2010:299), and educational programmes (Cowley, 2007:1; Robertson, 2007:1). Internationally, corporate institutions have accepted their social responsibilities as corporate citizens by investing substantially to school education (Habisch, Mester \& Scmidpeter, 2001; Logsdon \& Wood, 2005; Maignan \& Ferrel, 2001; Matten \& Crane, 2005; Matten, Crane \& Chapple, 2003). In the quotation below we see the importance of social responsibility:

'The crux of social responsibility is, however, the insistence of the community that business should in every respect be a "good corporate citizen", one that produces profits for its owners and investors but simultaneously markets safe products, combats pollution, respects the rights of employees and consumers and assists the disadvantaged. In short, businesses are expected to promote the interests of society' (Van den Ende, 2004:2).

Thus, proactive SGBs of public schools, as part of their creative or innovative approach to fundraising, will aim to attract as many corporate institutions as possible to ensure sustainable sources of school funding (Motala, 2005:51). Schools are encouraged to focus on the 20 percent of stakeholders that supply 80 percent of donations rather than expending energy on fundraising activities that do not yield a substantial return (Adiar, 2011:1). Thus, one of the aims of fundraising initiatives should be to identify and build mutually beneficial relationships with the 20 percent of corporate institutions that provide 80 percent of donations (Bernstein, 2010:29). Such relationships are only evident when both parties share responsibility by challenging one another and ensuring that they account for 'what they are doing and what they are not doing' (Young, 2008:162). SGBs should develop relevant knowledge and skills to ensure and sustain mutually beneficial relationships when requesting private funding to supplement state resources (Adler, 2008:388-399). Thus, training and development of fundraising knowledge and skills for SGBs and principals should be made available.

It is vital to understand that the mere availability of corporate funding does not automatically mean that such funding is and will remain available to all schools (Seekings \& Nattrass, 2006:396). Corporate funding in schools should not be taken for granted. The deep links between corporates and the public schools located in communities which they serve must be uncovered (Shrivastava, 2008:18). If this matter is not treated with the utmost urgency, the availability of corporate funding in public schools will be reduced dramatically. The reality is that corporate institutions are not obliged to provide funding to schools. By simply doing business, paying taxes and creating employment they are indirectly funding public schools (Bernstein, 2010:34). Corporate institutions that allocate funds to schools that are not in their direct scope of interest is praiseworthy, but not obligatory, as it has little effect on the nature and quality between the firm and its "real" stakeholders (Phillips \& Freeman, 2008:105). Corporate institutions are funding organizations to fulfil their responsibility as corporate citizens. They are indeed selective and are no longer giving to whoever knocks on their door (Van den Ende, 2004:92).

Corporate social spending trends are also slowly moving away from education towards other initiatives such as combating HIVIAids and crime (Van den Ende, 2004:69). This slow change is due to evidence that all learners in South Africa are not receiving quality education; even with increased state and private funding (Bernstein, 2009:4; Motala \& Dieltiens 2010:2). Fortunately, for public schools requesting funding, the common perception amongst corporate institutions is that commercial success is dependent on a well-educated population (Adler, 2008:388). Corporate institutions require people who are well-educated to survive and for this reason they will most likely offer support to schools delivering quality education (Van den Ende, 2004:69).

We used the Deleuzian Rhizomatic Perspective (DRP) theory as a framework to underpin this study. This theory advocates the concept of 'the black hole is on the white wall' (Deleuze \& Guattari, 1987:182) which essentially means that 'visible reality, symbols and images are not always what they seem to be' (Schipper \& Bojé, 2008:513). A corporate institution that invests funds in a public school is a social good (white wall), but there exists some self-serving motive (black hole) behind such an investment; which is not necessarily made public (Schipper \& Bojé, 2008:513). By only concentrating on the social good (white wall), a superficial picture of openness and integrity is created (Ludescher, McWilliams \& Siegel, 2008:328). The self-serving motive (black hole) must come to light. By doing so, we can eradicate the illusion that corporate institution funding in a public school (and other social causes) is a simple ploy to keep up appearances (Schipper \& Bojé, 2008:513; Waddock, 2008:69; Shrivistava, 2008:183). Interestingly, there are always social returns for actions motivated by private returns (the same relationship cannot be said for actions purely motivated by social returns). For example, 'providing day care may lower the number of juvenile crimes in a community (white wall), but the firm might provide the day care only because it increases the availability of workers and lowers the cost of 
absenteeism (black hole)' (McWilliams, Siegel \& Wright, 2006:9). The 'black hole' is not a pseudonym for a 'negative' variable nor does it necessarily mean profit. The 'black hole' is the measurable outcome demanded by corporate institutions that is not necessarily made public (Schipper \& Bojé, 2008:513). It could come in the form of a corporate institution demanding that a mutually beneficial relationship should exist between the donor and beneficiary (Phillips \& Freeman, 2008:114).

\section{Findings}

From the document and interview analysis the following four themes emerged:

\subsection{Theme one: Sources of corporate funding to public schools}

The motivation for corporate institutions investing funds in public schools located in the central district of Cape Town was investigated. The allocation of corporate funding to public schools was also verified. The participants confirmed that they made funding available to public schools. Four potential sources of corporate funding to supplement state resources in public schools were identified: Corporate Social Investment (CSI); Employee Involvement Programmes (EIP); CauseRelated Marketing (CRM); and Customer Relationship Practices (CRP) (Kotler, Hessekiel \& Lee, 2012; Hawkins, 2012; Trialogue, 2008).

CSI refers to financial (at least 1\% of profit after tax and non-cash contributions (such as EIP) aimed at developing and empowering previously disadvantaged and under-privileged individuals and communities (South Africa, 2003; Trialogue, 2008:18). With reference to EIP, two components were revealed during the analysis of corporate documents, namely, employee volunteerism and payroll giving. Employee volunteerism, from the perspective of corporate institutions, refers to the opportunity granted to employees to become part of sustainable initiatives in the community where they live and/or work. This is in-line with the corporate's CSI strategy. Employees who join the programme and who dedicate their free-time to serve the less fortunate receive the following: a financial contribution (from the CSI budget) to put towards the organisation; and time off to work in the organisation.

Corporate THREE's Social Report for the 2012 financial year concerning employee volunteerism uncovered the following: 'The aim of our employee volunteer programme is to progressively draw Corporate THREE close to the social causes integral to the business context, for which we all have a responsibility to respond'. To clarify the level of support given to a school via employee volunteerism, Corporate FIVE specifically stated: 'The programmes that we initiate are not there to do their (teachers) work for them, but to act as an additional resource'. To emphasise this point, Corporate THREE's Social Report clearly states that: 'The aim is to increase the capacity of our beneficiaries rather than maintain their ongoing dependence on us'.

Payroll giving as a component of EIP allows employees to make direct monetary contributions (monthly deductions from their salaries) to pre-selected (employee nominated) charities as identified by employees. It was revealed that no public school has thus far been nominated as a beneficiary of payroll giving. It must be noted that the corporates disclosed that 'underprivileged public schools do qualify for nomination' as a beneficiary of payroll giving. The corporate institutions explained that 'Payroll giving is capped at $5 \%$ of an employee's salary'. This means that, as an example, if a hundred employees who earn R5 000 a month donated 5\% to an underprivileged school; such a school could have an additional R25 000 every month to enhance the quality of teaching and learning practices.

Finally, CRM and CRP are acts of "linking monetary or in-kind donations to product sales or other consumer actions" (Kotler, et al., 2012:82; Hawkins, 2012:1783). The difference between CRM and CRP is the beneficiary of the donation. CRM activities raise funds for under-resourced schools serving the poorest of the poor. CRP activities raise funds for affluent schools. It must be noted that, within this sample of corporates, CSI spending (which includes EIP and CRM) was always higher (or at least equal) and more frequently applied when compared to CRP spending. Table 1 illustrates this finding: 
Table 1: The highest amounts the sampled corporates invested in an individual school

\begin{tabular}{|l||c|c|}
\hline Participant & $\begin{array}{c}\text { Highest Amount Mentioned in an Under- } \\
\text { Resourced School }\end{array}$ & $\begin{array}{c}\text { Highest amount Mentioned in an Affluent } \\
\text { School }\end{array}$ \\
\hline Corporate ONE & R50 000 per year in one school & R50 000 per year in one school \\
\hline Corporate TW0 & R75 000 per year in one school \\
\hline Corporate THREE & R25 000 per year in one school \\
\hline Corporate FOUR & R100 000 per year in one school \\
\hline Corporate FIVE & R135 000 per year in one school & R 0 per year in one school \\
\hline
\end{tabular}

Corporate ONE has awarded R50 000 to an under-resourced school (CRM) and also paid R50 000 over to an affluent school (CRP). Corporate TWO awarded R75 000 to an under-resourced school (CSI) and the highest amount mentioned for an affluent school was R25 000 (CRP). Corporate THREE, Corporate FOUR and Corporate FIVE did not participate in CRM or CRP and funded individual schools by means of CSI and EIP. Hence, evidence emerged that there is a link between sources of corporate funding for a public school and the industry in which a corporate institutions operate. To elaborate this, the sampled corporates who sell groceries and household items (Corporate ONE and Corporate TWO) used CSI, EIP, CRM and CRP as potential sources of funding for a public school. Corporate institutions who operate in the financial, insurance or construction industry (Corporate THREE, Corporate FOUR and Corporate FIVE) only made substantial funding available to public schools in the form of CSI and EIP.

\subsection{Theme two: Corporates sustainability of their own economic future}

According to the sampled corporate institutions, one of the main reasons to invest in a public school was to be part of the process of realising economic growth (the so-called black hole) by rectifying the injustices caused by the apartheid legacy (white wall) (Deleuze \& Guattari, 1987:182). Within this context, Corporate TWO's Chief Executive Officer (CEO) specifically stated the following in a letter featured in their Sustainability Report for the 2012 financial year: 'There's an ignitable spirit of volunteerism present in every one of us. When we choose to spark it, we find ourselves not so much reassured that our contribution is of value (realising economic growth), but rather we are humbled by the scale of the challenges (injustices of the past) people face.' For this reason, the bulk of corporate funding made available to a public school occurs in the form of CSI (including CRM and EIP) aimed at rectifying the injustices of the past and to stimulate economic growth (Bernstein, 2010:34). The sampled corporates perceive the children (as future entrepreneurs [suppliers and business partners], employees and consumers) will play a pivotal role in promoting South Africa to reach its full economic potential. Hence, at its core, an investment in a public school is an indirect long-term investment that will help sustain the corporate institution's own economic future (Rangassammi \& Van Hille, 2011:63; Bernstein, 2009:34). This can be achieved by helping mainly those learners who do not have adequate financial support to realise their full economic potential (Modisaotsile, 2012:3; Van der Berg, 2008:14-15).

By investing in a public school, corporate institutions are accorded the opportunity to build a reputation as a compassionate organisation that is willing to invest in South Africa's people. Corporate ONE specifically stated: 'We are allowed to give feedback to our customers on donations we made through our website and through PR activities. If there are additional branding opportunities, we will negotiate this with the school.' Corporate TWO revealed that they invest in schools 'to nurture a reputation amongst stakeholders for being a compassionate organisation'.

The corporate institutions were also able to identify new business opportunities by means of accessing untapped markets or tendering as suppliers for state funded education projects. Within this context, Corporate FOUR's Sustainability Report for the 2010 financial year disclosed the following: 'CSI initiatives, such as funding a public school, are sometimes used by the business units as a way to gain an understanding of new markets. It allows us to be more responsive to socio-economic and environmental trends. This can also generate goodwill.' Corporate TWO's CSI policy specifically states: 'Divisions will, wherever possible, establish synergies between commercial priorities and our CSI involvement. This may involve leveraging our CSI initiatives in order to consolidate our position in existing markets or to gain access to new business opportunities, such as those offered by supply to government funded feeding schemes.'

By investing in a public school, corporate institutions also gained access to networking opportunities with other 
institutions and state agencies when resources were pooled together to achieve a sustainable impact. Corporate THREE stated that the pooling of resources is the only real hope to make a significant and sustainable impact in individual schools and communities. Our aim is to bring about change through working with partners and pooling resources. Schools create unique opportunities for collaborations and partnerships, which companies have begun to explore for mutual benefit.' Within this context, Corporate FIVE stated: 'We encourage other corporates, state agencies and individuals to join us in our quest to turn schools into centres of excellence'.

Finally, by investing in a school, corporate institutions believe that they help in the development of a stable and prosperous society which will ultimately lead to a sustainable supply of consumers, suppliers and employees (economic growth). Corporate FOUR posits the following: 'Corporates support teachers and those working in education in their efforts to ensure that the youth in economically and socially disadvantaged communities have a better chance of succeeding in life. Helping improve the future living standards in these communities helps to improve the health, education and productivity of our future employees and also increases the pool of future purchasers of insurance products.' The common thread revealed that the probability of achieving the above mentioned business objectives were greatly increased when employee involvement in CSI practices were the norm. The Social Report for the 2012 financial year of Corporate THREE made known that: 'The aim of our employee volunteer programme is to progressively draw Corporate THREE close to the social causes integral to the business context, for which we all have a responsibility to respond'. The impact of CSI was greatly enhanced by EIPS as a way of 'pooling resources (CSI, EV and PG) to make a significant and sustainable impact'. Hence, evidence exists that the sustainability of CSI funding in a public school is potentially dependent on the level of employee involvement (EV and PG) a school is able to solicit. Within this circumstance, Corporate FOUR explicitly stated that: 'We launched our employee involvement programmes in 2009. Staff awareness campaigns were developed and implemented to encourage staff to nominate their projects for continued funding and support'.

In summary, corporates make funding available to public schools in exchange for both private (reputation building; networking; new business opportunities) and social returns (stable and prosperous society) (Van den Ende, 2004:iv).

\subsection{Theme three: Evaluating funding requests made to corporates}

This theme provides a good understanding of how various corporate institutions evaluate funding requests received from public schools. The participants confirmed that corporate institutions follow strict policy guidelines during the evaluation of a funding proposal.

Based on document analysis we established that each of the sampled corporate institutions had a particular focus that facilitated the selection process to award funding to schools: Corporate ONE considered schools and projects that aligned with the CSI policy and strategy. These schools had to be in specific locations or regions and required specific types of donations. Corporate TWO considered applications that focused on CSI activities primarily in three areas: education, feeding schemes and HIVIAids. Corporate THREE had a strong focus on investing in vulnerable communities. Financial need and academic excellence remains the two major factors considered for access to funding. Corporate FOUR's focused on three strategic areas: youth development, youth entrepreneurship and youth security. Corporate FIVE committed funds to a public school based on the resource needs of the school.

All the sampled corporate institutions had CSI policy guidelines that required schools to adhere to when making application for funding. Schools were required to submit two reports: a narrative report which involved descriptive information to explain the purpose for the funding and explain how the intended initiative would impact on school improvement over a specific period of time; and a financial (budget) report, also known as a statement of proposed income and expenditure. If funding is awarded, this aspect of the proposal would serve as a monitoring and control tool to identify problems before the school runs into any financial difficulties.

The common policy evaluation criteria used by corporates once the shortlisting of potential CSI beneficiaries were established are as follows:

- Schools should submit the funding proposal in a timeous and professional manner along with audited financial statements;

- Schools should be located in a corporate's customer catchment area and that they should communicate a track record of success in the community.

- The proposal should include the contact details of the person with decision-making power and who have the support of all school stakeholders.

- The SGB and principal should be willing to take ownership of the initiative with clear timelines of how long 
corporate support will be required

The participants emphasized that public schools are required to do a self-evaluation of their funding proposal before submitting it to the identified corporates. There was consensus that a good funding proposal creates a profound professional image of the school and 'makes a good first impression'. The corporate institutions emphasized that they don't adhere to 'cheque-book charity', but rather concentrate on 'assisting communities to help themselves'. By submitting a good funding proposal, the school attests to corporate institutions that they are committed to undertaking projects with the aim of uplifting the community they serve.

When making the final evaluation of the funding proposals received from public schools, corporate institutions would use the following criteria:

- Affordability of the requested funding: In most cases, corporate institutions will select the proposed initiative that requires the lowest amount of corporate resources but one that will be able to make the largest measurable impact against a real problem affecting the quality of teaching and learning practices in underresourced schools.

- Relevancy of the requested initiative: Corporates evaluate a funding proposal to verify that the target beneficiaries of the proposed initiative are indeed the poor of the stakeholders of the corporate.

- Consistency with state education policy Corporates show preference to a funding proposal from a school that is anchored in a researched initiative supported by state policy and intervention. This is aligned with the corporates' intention to supplement funding provided by the state. Corporates wish to uplift communities and understand that the state cannot solve all the social problems of the country on its own.

- Requests should be in-line with an approved CSI plan. A good funding proposal that is submitted timeously can greatly influence a corporates decision making process when deciding on initiatives to include as priority items on the CSI plan for the coming financial year.

\subsection{Theme four: Relationship building}

One of the conditions for corporate institutions funding public schools is to get something back from the funded schools. A social return should be achieved to allow corporates to realise their business objectives in exchange for funding public schools. In this way mutual beneficial relationships are built.

To emphasise this, corporate institutions acknowledged that 'a mutually beneficial relationship must be established to ensure that a real difference is made to a real problem'. Only once a real difference is made (social return), corporate institutions are able to realise their business objectives (private returns). Hence, there is evidence that a potential causeand-effect relationship exists between social and private returns. Once a substantial social return (from the perspective of the corporates' stakeholders) is achieved, are private returns (reputation building, networking, consumer loyalty, and/or identifying new business opportunities) realised. A mutual beneficial relationship between a corporate and a public school is therefore dependent on solving serious social problems affecting the overall academic performance of schools. Thus, a mutual beneficial relationship is anchored in an initiative that requires corporate funding and support to yield a social return (Kotler et al., 2012:239-251; Adler, 2008:388-399). The corporate institutions revealed that from their experiences, initiatives that successfully made a difference to a real social problem met the following requirements:

Corporates revealed that an initiative that addressed a specific need of the community allowed for the realisation of private and social returns (a mutual beneficial relationship). Within this context, the participant from Corporate TWO specifically stated: 'Initiatives must be underpinned by realistic and measurable social development objectives in order to realise business benefits associated with involvement in the initiative'. The corporate institutions require initiatives to enhance the quality of teaching and learning practices in schools for them to have the potential to become self-sustained. Corporate THREE emphasized that: 'Our aim is to bring about change. We hope to make a significant and sustainable impact. We try to increase the capacity of our beneficiaries rather than maintain their ongoing dependence on us.'

The other sampled corporate institutions revealed that initiatives must be anchored in good governance and sound financial control. Within this context, Corporate TWO's Sustainability Report for the 2012 financial year revealed that: 'Corporate Social Investment has also been identified as an area of risk. It is essential for divisions to ensure symmetry of interests and goals when developing relationships with any government entity and importantly that any giving, however small, is free from even the taint of fraud and corruption.

Lastly, initiatives must be unique and learner-orientated to realise a mutually beneficial relationship. Within this context, Corporate FOUR stated that a unique initiative answers the following question: 'What do young people need to become relevant and successful in their world?' Corporate THREE added that: 'The initiative must prove to learners that 
whatever their background looks like, it doesn't mean that they have to be stuck there. The initiative must encourage them to have aspirations that reach beyond the limitations of their circumstances'. Hence, the initiative should be unique and anchored in a creative understanding of how to improve the quality of teaching and learning practices in a school's unique context (Kotler et al., 2012:239-252; Adler, 2008:388-399).

To summarise, a mutual beneficial sustainable relationship between a corporate and a school exists when a school has the potential to become a champion ('underprivileged schools that overcome challenging circumstances') in environments where others fail. This means that a school should focus on developing their ability to continuously generate unique and context specific initiatives to solve problems in the school with the potential to become selfsustained. If an initiative fails, a mutual beneficial relationship can still be maintained as long as the school remains open and honest concerning the reasons for failure. The school should identify the causes for failure and present a new approach with a greater probability of success as established with the experience gained from the failure. Corporate THREE specifically stated: 'We constantly strive to hold our beneficiaries accountable for effective implementation of practice and procedure, but we recognise the difficulties and ongoing challenges that this still presents.'

\section{Conclusion and Recommendations}

Corporate funding is an art rather than a simple manual process. Most corporates do not fund schools on an ad-hoc basis but follow strict policy guidelines to evaluate funding requests from schools. Most corporate institutions are prepared to invest funds in public schools in exchange for private returns which include: increased sales and a big slice of the market share; strengthened brand positioning; enhanced corporate image; increased ability to attract, motivate and retain employees; a decrease in operating costs; and an increased appeal to investors. It is evident that a mutually beneficial relationship should exist between a corporate and the public schools, so that schools can achieve their goals of providing quality education.

The focus of this study was to establish the motivation for corporate institutions to invest funds in public schools. It is evident that successful schools have to submit well-structured funding proposals as one means of persuading corporate institutions to fund them. This study revealed that the sustainability of CSI funding in a public school is potentially dependent on the level of employee involvement and payroll giving. Employees are encouraged to become part of sustainable initiatives in the community where they live and/or work that is in-line with the corporate's CSI strategy. Payroll giving allows employees to make direct monetary contributions (monthly deductions from their salaries) to preselected (employee nominated) charities as identified by employees.

In keeping with the findings, the following recommendations are proposed to so that schools can access funding from corporate institutions thereby enhancing the quality of teaching and learning practices: A training programme should be developed for SGBs, principals and teachers on how public schools can solicit and sustain corporate funding. The training should focus the different sources of corporate funding available to public schools; the "how" behind a good funding proposal; how teachers can utilise available resources to its maximum potential before additional resources are requested; understanding when and how a proposed initiative can be anchored in a mutual beneficial relationship between a corporate and a school. We also recommend that Higher Education Institutions develop and offer to all school and district managers a short part-time course on Financial Management which focuses, amongst others, the leadership and management of Fundraising Projects.

\section{References}

Adiar, I. (2011). 'Analyzing Fundraising Strategies through the 80/20 Principle' in The Fundraising Authority Newsletter. joe@thefundraisingauthority.com. (Accessed, 23 September 2011)

Adler, NJ. (2008). Global Business as an Agent of World Benefit: New International Business Perspectives Leading Positive Change in A.G. Scherer \& G. Palazzo (eds.), Handbook of Research on Global Corporate Citizenship, Cheltenham: Edward Elgar.

Anderson, JW. (1998). Corporate Social Responsibility - Guidelines for Top Management: Connecticut: Greenwood Press Inc.

Bernstein, A. (2010). The Case for Business in Developing Economies, Johannesburg: Penguin Books.

Bernstein, A. (2009). Introductory remarks in International Best Practice in Schooling Reform: What can South Africa Learn from Other Countries? Johannesburg: The Centre for Development and Enterprise.

Blake, BS. (2008). 'The Principal as Entrepreneur in the Management of Schools', M.Ed. Minor-Dissertation (unpublished), Dept. of Education Management, Johannesburg: University of Johannesburg.

Bray, R., Gooskens, I., Kahn, L., Moses, S. \& Seekings, J. (2010). Growing Up in the New South Africa: Childhood and Adolescence in Post-Apartheid Cape Town. Cape Town: HSRC Press.

Butler, A. (2009). Contemporary South Africa, $2^{\text {nd }}$ Edition, Palgrave, London: Macmillan. 
Caelli, K., Ray L., \& Mill, J. (2003). 'Clear as Mud': Toward Greater Clarity in Generic Qualitative Research, International Journal of Qualitative Methods, Spring 2(2), 1-24.

Cannon, T. (1992). Corporate Responsibility, London: Pitman Publishing.

Cohen, L., Manion, L. \& Morrison, K. (2011). Research Methods in Education, Abingdon: Routledge.

Cowley, P. (2007). 'Should Schools Accept Corporate Funding? We Asked Two Experts to Give us the Pros and Cons.' http://www.todaysparent.com/education/general/article.jsp?content=20070409_101345_4656\&page=1.

(Accessed on 5 September 2011).

Deleuze, G. \& Guattari, F. (1987). A Thousand Plateaus: Capitalism and Schizophrenia, London: University of Minneapolis Press.

De Vos, AS., Strydom, H., Fouche, CB., \& Delport, CSL. (2002). Research at Grassroots: For the Social Sciences and Human Services Professions, $2^{\text {nd }}$ Edition., Pretoria: Van Schaik.

Esser, IM. \& Dekker, A. (2008). 'The Dynamics of Corporate Governance in South Africa: Broad Based Black Economic Empowerment and the Enhancement of Good Corporate Governance Principles', Journal of International Commercial Law and Technology, 3(3), 157-166.

Flanagan, L. (2011). 'Joburg Metro's R12bn Debt Highest in Land', The Star, 6 September, 2011, p. 6.

Flick, U. (2007). Designing Qualitative Research: The SAGE Qualitative Research Kit, London: SAGE.

Griesel, I. (2011). 'The Teaching of Financial Management Principles to School Leaders in Disadvantaged Schools', D.Ed. Thesis (unpublished). Nelson Mandela Metropolitan: Department of Education, Nelson Mandela Metropolitan University.

Habisch, A., Mester, HP \& Schmidpeter, R. (eds). (2001). Corporate Citizenship as Investing in Social Capital, Berlin: Logos.

Hanushek, EA. \& Wößmann, L. (2007). Education Quality and Economic Growth, Washington: The International Bank for Reconstruction and Development.

Hawkins, R. (2012). 'A New Frontier in Development? The Use of Cause-Related Marketing by International Development Organisations', Third World Quarterly, 33(10), 1783-1801.

Karlsson, J., McPherson, G. \& Pampallis, J. (2001). 'A Critical Examination of the Development of School Governance Policy and its Implications for Achieving Equity' in E. Motala \& J. Pampallis (eds.), Education and Equity: The Impact of State Policies on South African Education, Sandown: Heinemann.

Kotler, P., Hessekiel, D. \& Lee, NR. (2012). Good Works! Marketing and Corporate Initiatives that Build a Better World... and the bottom line, New Jersey: John Wiley \& Sons.

Krefting, L. (1990). 'Rigor in Qualitative Research: The Assessment of Trustworthiness', The American Journal of Occupational Therapy, March 1991, 45(3), 214-222.

Leedy, PD. \& Ormrod, JE. (2005). Practical Research: Planning and Design, 8th Edition, New Jersey: Pearson Education.

Logsdon, JM. \& Wood, DJ. (2005). 'Global Business Citizenship and Voluntary Codes of Ethical Conduct', Journal of Business Ethics, $59,55-67$

Lincoln, YS. \& Guba, EG. (1985). Naturalistic inquiry, California: SAGE.

Ludescher, JC., McWilliams, A. \& Siegel, DS. (2008). The Economic View of Corporate Citizenship in A.G. Scherer \& G. Palazzo (eds.), Handbook of Research on Global Corporate Citizenship, Cheltenham: Edward Elgar.

Maignan, I. \& Ferrel, OC. (2001). 'Corporate Citizenship as a Marketing Instrument: Concepts, Evidence and Research Direction', European Journal of Marketing, 35, 457-84.

Makhubela, BS. (2005). 'The Role of the School Governing Body in Financial Administration at Sokisi Secondary School: A Case Study', M.Ed. Minor-Dissertation, Johannesburg: Department of Education Management, University of Johannesburg.

Matten, D., Crane, A. \& Chapple, W. (2003). 'Behind the Mask: Revealing the True Face of Corporate Citizenship', Journal of Business Ethics, 45, 109-20.

McWilliams, A. \& Siegel, D. (2001). 'Corporate Social Responsibility: A Theory of the Firm Perspective', Academy of Management Review, 27, 15-17.

McWilliams, A., Siegel, DS. \& Wright, PM. (2006). 'Corporate Social Responsibility: Strategic Implications', The Journal of Management Studies, 43(1), 2367-2380.

Author 1. (2004). 'Financial Accountability: The Principal or the School Governing Body?', South African Journal of Education, 24(2), 126-132.

Modisaotsile, BM (2012). 'The Failing Standard of Basic Education in South Africa', Policy Brief, Africa Institute of South Africa, Briefing No. 72, March 2012, www.ai.org.za. (Accessed on 15 November 2011).

Motala, S. (2005). 'Finance Equity in the South African Schooling System' in S. Motala \& J. Pampallis (eds.), Governance and Finance in the South African Schooling System: The First Decade of Democracy, Johannesburg: CEPD.

Motala, S. \& Dieltiens, V. (2010). Educational Access in South Africa: Country Research Summary, CREATE, Johannesburg: The Education Policy Unity, University of the Witwatersrand.

Pampallis, J. (2008). School Fees, Issues in Education Policy Number 3, Johannesburg:CEPD.

Phillips, RA. \& Freeman, RE. (2008). Corporate Citizenship and Community Stakeholders in A.G. Scherer \& G. Palazzo (eds.), Handbook of Research on Global Corporate Citizenship, Cheltenham: Edward Elgar.

Schipper, F. \& Bojé, DM. (2008). Transparency, Integrity and Openness: The Nike Example in A.G. Scherer \& G. Palazzo (eds.), Handbook of Research on Global Corporate Citizenship, Cheltenham: Edward Elgar.

Rangasami, J. \& Van Hille, N. (2011). 'Maximising the Positive Social Impact of CSI Funds', The CSI Handbook, 14th Edition, Cape Town: Trialogue,. 
Robertson, HJ. (2007). 'Should Schools Accept Corporate Funding? We Asked Two Experts to Give us the Pros and Cons'. http://www.todaysparent.com/education/general/article.jsp?content=20070409_101345_4656\&page=1. (Accessed on 5 September 2011).

Scherer, AG. \& Palazzo, G. (eds). (2008). Handbook of Research on Global Corporate Citizenship, Cheltenham: Edward Elgar.

Seekings, J. \& Nattrass, N. (2006). Class, Race, and Inequality in South Africa, Scottsville: University of KwaZulu-Natal Press.

Sethi, SP. (2008). Defining the Concept of Good Corporate Citizenship in the Context of Globalization: A Paradigm Shift from Corporate Social Responsibility to Corporate Social Accountability in A.G. Scherer \& G. Palazzo (eds.), Handbook of Research on Global Corporate Citizenship, Cheltenham: Edward Elgar.

Shrivastava, P. (2008). Corporate Citizenship and the Environment in A.G. Scherer \& G. Palazzo (eds.), Handbook of Research on Global Corporate Citizenship, Cheltenham: Edward Elgar.

Solomon, RC. (2008). Business Ethics, Corporate Virtues and Corporate Citizenship in A.G. Scherer \& G. Palazzo (eds.), Handbook of Research on Global Corporate Citizenship, Cheltenham: Edward Elgar.

South Africa. (2003). Broad Based Black Economic Empowerment, Act 53 of 2003, Cape Town: Government Printers.

South Africa. (1998). National Norms and Standards for School Funding, Cape Town: Government Printers.

South Africa. (1996). South African Schools Act 84 of 1996, Cape Town: Government Printers.

Spaull, N. (2012). 'Special Focus: The Writing's on the Board, Naptosa Insight, 6(2), 8-14.

Statz, B. \& Weber, P. (2010). 'SFO Certification: Recognizing High Standards for Managers of School Business Operations Today', School Business Affairs, 76(6), 8-11.

Theobald, S. (2002). Future Wealth, Financial Mail, 168(11), 24-26.

Tesch, R. (1990). Qualitative Research, New York: Falmer Press.

Tladi, B. \& Mulaudzi, M. (2003). 'School Governing Bodies in Limpopo Province: Challenges, Strenghts and Weaknesses in District Development Support Programme', Improving the Quality of Primary Education: Good Practices and Emerging Models of District Development, Pretoria: DDSP.

Trialogue. (2008). The CSI Handbook, 11 th Edition. Cape Town: Trialogue.

Tshikululu Social Investments. (2011). 'Our Expertise: Education Sector'. http://www.tshikululu.org.za/our-expertise/education/. (Accessed on 5 August 2011).

Van den Ende, L. (2004). 'Corporate Social Responsibility in South Africa: Fact or Fiction', M.Com. Dissertation (unpublished), Johannesburg: Dept. of Business Management Rand Afrikaans University.

Van der Berg, S. (2008). Poverty and Education, Education Policy Series Booklet 10, Paris: The International Institute for Educational Planning (IIEP).

Veriava, F. (2010). The Resourcing of Public Schools: An Analysis of Compliance with, and Measurement of the State's Constitutional Obligations, Research Paper for the Studies in Poverty and Inequality Institute (SPII). http://www.spii.org.za/agentfiles /434/file/Review\%20of\%20Education\%20Policy.pdf.

(Accessed on 7 August 2012).

Waddock, SA. (2008). Corporate Responsibility/Corporate Citizenship: The Development of a Construct in A.G. Scherer \& G. Palazzo (eds.), Handbook of Research on Global Corporate Citizenship, Cheltenham: Edward Elgar.

Young, IM. (2008). Responsibility and Global Justice: A Social Connection Model in A.G. Scherer \& G. Palazzo (eds.), Handbook of Research on Global Corporate Citizenship, Cheltenham: Edward Elgar. 